\title{
HVMANITAS
}

\section{Nos 2500 anos da Batalha de Maratona}

Autor(es): $\quad$ Rodrigues, Nuno Simões

Publicado por: Faculdade de Letras da Universidade de Coimbra, Instituto de Estudos

URL

persistente: URI:http://hdl.handle.net/10316.2/8528

DOI: $\quad$ DOI:http://dx.doi.org/10.14195/2183-1718_62_4

Accessed : $\quad$ 26-Apr-2023 16:19:06

A navegação consulta e descarregamento dos títulos inseridos nas Bibliotecas Digitais UC Digitalis, UC Pombalina e UC Impactum, pressupõem a aceitação plena e sem reservas dos Termos e Condições de Uso destas Bibliotecas Digitais, disponíveis em https://digitalis.uc.pt/pt-pt/termos.

Conforme exposto nos referidos Termos e Condições de Uso, o descarregamento de títulos de acesso restrito requer uma licença válida de autorização devendo o utilizador aceder ao(s) documento(s) a partir de um endereço de IP da instituição detentora da supramencionada licença.

Ao utilizador é apenas permitido o descarregamento para uso pessoal, pelo que o emprego do(s) título(s) descarregado(s) para outro fim, designadamente comercial, carece de autorização do respetivo autor ou editor da obra.

Na medida em que todas as obras da UC Digitalis se encontram protegidas pelo Código do Direito de Autor e Direitos Conexos e demais legislação aplicável, toda a cópia, parcial ou total, deste documento, nos casos em que é legalmente admitida, deverá conter ou fazer-se acompanhar por este aviso. 
humanitas

Vol. LXII

2010 


\title{
NOS 2500 ANOS DA BATALHA DE MARATONA
}

NunO Simões RodRIGUES

Universidade de Lisboa

\section{Resumo}

Este texto pretende evocar a batalha de Maratona, no ano em que se completam dois milénios e meio sobre o acontecimento.

Palavras-chave: Batalha de Maratona, Guerras Medo-Persas, Atenas.

\begin{abstract}
This text aims to remind the Battle of Marathon in the year that completes two Millenia and half on the event.

Key-words: Battle of Marathon, Persian Wars, Athens.
\end{abstract}

Entre 490 e 479 a.C., a Grécia viveu momentos cruciais, conhecidos como as Guerras Medo-Persas, com repercussões que viriam a determinar não apenas a sua História como a de toda a Europa. Um desses momentos decorreu precisamente em 490 a.C., aquando da chamada Primeira Guerra Médica, numa batalha que decorreu na Ática, no lugar de Maratona, e que viria ser um dos mais importantes acontecimentos da História da Grécia Antiga. Em 2010, completam-se dois mil e quinhentos anos sobre o conflito.

$\mathrm{Na}$ sequência do desaparecimento do Império Neo-Assírio, às mãos dos Medos dos Babilónios, a Pérsia emergiu como o poder próximooriental que viria a reivindicar o domínio sobre grande parte das cidades do Mediterrâneo levantino. Em 549 a.C., Ciro estendia já o seu poder sobre a Lídia e as cidades gregas da Ásia Menor. Entre 529 e 522 a.C., foi a vez do seu filho, Cambises, conquistar o Egipto, o que confirmou o 
Império Persa como potência hegemónica. A consolidação do Império, porém, deu-se com Dario (521-486 a.C.), que enfrentou uma revolta das cidades gregas da Jónia, em 499 a.C., encabeçada pelos tiranos então no poder. Um desses tiranos foi Aristágoras de Mileto, que procurou a ajuda da Hélade ocidental no processo. Esparta recusou-lhe a ajuda, mas Atenas, com o apoio da cidade eubóica de Erétria, percebendo o perigo que vinha de leste, decidiu enviar para o cenário de guerra um destacamento militar, constituído por um corpo de hoplitas.

Atenienses e aliados chegaram a Sárdis e incendiaram a cidade em 498 a.C. Mas, quatro anos depois, os Persas reagiram, invadiram a Jónia e esmagaram a revolta das populações locais. A crer no testemunho de Heródoto, o saque de Mileto traumatizou o pensamento colectivo de então, como teria mostrado a desaparecida tragédia de Frínico, A Queda de Mileto ${ }^{1}$.

Reorganizado, Dario dirige então os seus esforços para a Grécia ocidental. O general persa confia o comando de parte das suas tropas a um sobrinho e genro, Mardónio, o qual, em 492 a.C., submete a Trácia, a ilha de Taso e a Macedónia ao poder dos Persas. Dois anos depois, em 492 a.C., uma frota persa chefiada por Dátis e Artafernes avança sobre a Eubeia, ataca Erétria e destrói-a. Depois, os Persas desembarcam na Ática, na localidade de Maratona. Não é impossível que a decisão de desembarcar nesse lugar se tenha devido a um antigo tirano de Atenas, Hípias. Em Atenas, perante $o$ ataque iminente dos Persas, o pânico instala-se. O conselho decide pedir auxílio aos Espartanos.

O testemunho é passado por dois autores antigos: Heródoto e Luciano. Segundo o historiador de Halicarnasso, antes do confronto, os estrategos atenienses incumbiram um homem de nome Filípides de contactar os Lacedemónios, para que estes fossem em auxílio dos Atenienses. Filípides teria então percorrido os $220 \mathrm{~km}$ que Atenas dista de Esparta em apenas um $\operatorname{dia}^{2}$. Mas, de acordo com Luciano, escritor do século II d.C., Filípides teria morrido a anunciar a vitória dos Atenienses em Maratona, depois de ter percorrido os 42,95 km que separam aquele demo da Ática da capital ${ }^{3}$. Apesar de a distância assinalada por Luciano ser menor, é mais provável

1 Hdt. 6, 21. A tragédia, hoje infelizmente desaparecida, poderá ter visto o seu Nachleben condicionado precisamente porque o governo ateniense teria proibido que voltasse a ser representada. Sobre esta questão, ver nota de J. Ribeiro Ferreira à tradução de Heródoto, Histórias - Livro $6^{\circ}$, Lisboa, 2000, 64.

2 Hdt. 6, 105-106.

3 Luc., Sobre um lapso cometido ao saudar frg. 3. 
a verosimilhança da versão herodotiana, visto que o historiador escreveu numa data muito próxima do acontecimento. Talvez haja apenas algum exagero no único dia que teria durado a empresa de Filípides. Além disso, a versão de Luciano está envolta em elementos patéticos, como o do anúncio da vitória dos Atenienses e a morte quase imediata do mensageiro, por exaustão e ansiedade. Apesar disso, foi esta versão tardia que mais se popularizou, difundiu e que serviu de mote para a prova da maratona nos Jogos Olímpicos da época moderna.

Acontece que, nessa ocasião, os Espartanos celebravam as Carnéades, pelo que, por motivos religiosos, recusaram-se a partir antes da Lua Cheia ${ }^{4}$. Foi assim que, com o um exército de cerca de dez mil homens e apenas o auxílio dos Plateenses, à volta de um milhar, Atenas enfrentou um inimigo bem mais poderoso. Entre os soldados, a capital da Ática tinha Ésquilo, aquele que viria a ser um dos seus grande dramaturgos, e o irmão deste, que todavia viria a perecer ali.

Do lado grego, Calímaco assumiu o comando. Mas o estratego da batalha foi Milcíades, que, estacionado na planície de Maratona, entre a montanha e o mar, aproveitou o facto de os Persas terem retirado parte das suas tropas para avançarem sobre Atenas para se lançar sobre o remanescente oriental ${ }^{5}$. Segundo Heródoto, 6400 persas foram massacrados, enquanto apenas 192 homens caíram do lado ateniense, entre os quais o seu polemarco Calímaco. Estamos claramente perante a tópica retórica do número da historiografia antiga - embora nem todos os achem exagerados -, mas ao que parece a vitória coube efectivamente aos Gregos. A propósito da batalha de Maratona, Heródoto oferece-nos algumas das suas mais belas páginas. Eis um exemplo:

Combateu-se durante muito tempo em Maratona: no centro do exército, saíram vitoriosos os bárbaros, onde estavam posicionados os próprios Persas e os Sacas. Nesse ponto, portanto, os bárbaros levaram a melhor e, rompidas as defesas, perseguiram os inimigos no interior; mas, mas partes laterais, foram os Atenienses e os Plateenses quem venceu. Embora tivessem ganho, deixaram escapar os bárbaros que se haviam posto em fuga, preferindo juntar as duas

4 Hdt. 6, 106.

5 Sobre a estratégia da batalha, ver N. Sekunda, Marathon 490 BC: The First Persian Invasion of Greece, London, 2002. Sobre as problemáticas políticas envolvidas, J. Ribeiro Ferreira, «A Batalha de Maratona e sua utilização política» in Heródoto, Histórias - Livro $6^{\circ}$, Lisboa, 2000, 20-28. 
alas e combater os que tinham rompido o centro das suas fileiras; e a vitória coube aos Atenienses. Depois, perseguiram os Persas em fuga, golpeando-os, até que, chegados ao mar, pegaram em fogo e atacaram os barcos...

Nesta batalha de Maratona pereceram, do lado dos Bárbaros, cerca de seis mil e quatrocentos homens, e, dos Atenienses, cento e noventa e dois. Foram quantos caíram de ambas as partes. ${ }^{6}$

Assim terminou a Primeira Guerra Médica. A batalha de Maratona marcou desde logo o imaginário popular dos Gregos, como mostra o facto de terem colocado nos frisos do Pártenon tantos cavaleiros quantos os Atenienses que caíram naquela refrega. Também Aristófanes chamou Marathonomachai aos combatentes de Maratona, usando-os como símbolo da coragem dos guerreiros da Atenas de outros tempos ${ }^{7}$. E o epitáfio de Ésquilo viria a assinalar como única glória do poeta apenas o facto de ele ter combatido em Maratona ${ }^{8}$.

6 Hdt. 6, 113; 117. Trad. D. F. Leão in Heródoto, Histórias - Livro $6^{\circ}$, Lisboa, 2000, 114-115

7 Aristof., Nub. 986.

8 Paus. 1, 14, 4-5; Plut., Moralia 604f; Ateneu 627d-e. 